\title{
THE ROLE OF STAKEHOLDERS IN CULTURAL ENTREPRENEURSHIP MANAGEMENT
}

\author{
Ieva Zemite
}

Latvian Academy of Culture, The University College of Economics and Culture, Latvia, zemite.ieva@gmail.com

\begin{abstract}
The skills and knowledge of the owners and employees of cultural enterprises on economic use of financial resources do not guarantee valuable artistic results. Therefore, a substantiated question has arisen: how to evaluate management in enterprises with bad financial ratios and outstanding artistic indicators. The existing definitions of cultural management (Aageson, 2008; Hagoort, 2007; Klamer, 1999; Stam, 2006; Nordman, 2003) also do not provide precise suggestions for determining the most important indicators in the evaluation of cultural management. The question is how to evaluate management in cultural entrepreneurship by determining the most important indicators for a cultural enterprise's performance improvement. In order to define the goal of the stakeholders' (artists, clients, media, arts scholars, third parties providing funds, cooperation partners) engagement, it is necessary to analyse the area of an enterprise's activities, and in what way and by what kind of activities it is possible to engage the stakeholders. During the course of empirical research, it is planned to disclose, analyse and interpret the subjective reasons of pursuit. Although a numerical evaluation of stakeholders was obtained during the research and data analysis performed by Spearman's rho correlation calculations, the obtained results during the interpretation have not been generalised. The research results reveal the role of the cultural enterprise's stakeholders' engagement in the evaluation of management, point to the importance of the goals' analysis as well as the analysis of each stakeholder's engagement, and define the criteria for evaluating the activities in cultural entrepreneurship.
\end{abstract}

Keywords: stakeholder's engagement; cultural entrepreneurship; culture management.

Type of the paper: Empirical study.

JEL Classification: Z10, L2

\section{Introduction}

The skills and knowledge of the owners and employees of cultural enterprises on economic use of financial resources do not guarantee valuable artistic results. Therefore, a substantiated question has arisen: how to evaluate management in enterprises with bad financial ratios and outstanding artistic indicators. The aim of the research is to define the role of stakeholders in managing cultural enterprises.

The research results reveal the role of the cultural enterprise's stakeholders' engagement in the evaluation of management, characterise the importance of the analysis of each stakeholder's engagement and indicate the criteria for evaluating the activities in cultural entrepreneurship.

To investigate the research topic, qualitative research methods have been chosen according to the problem to be investigated:

- General scientific methods: monographic method, logically constructive method, content analysis of qualitative research, analytic induction (theoretical aspects and practical research);

- Empirical research methods: in-depth, semi-structured interviews on stakeholer engagement;

- Data processing: for ascertaining the conformity of empirical distribution to normal distribution; review tables; Spearman's rho correlation.

A theoretical innovation has been proposed as a result of the research: the stakeholders' role in the evaluation of the enterprise's management has been revealed and the necessity for determining the 
mutual relationship of the stakeholders is disclosed, proposing it as a basis for the evaluation of cultural entreprise management.

\section{Literature Review}

To analyse the role of artistically valuable results within the context of managing cultural enterprises, it is necessary to evaluate the management of sustainable stakeholders (Jagersma, 2009, 341). The stakeholders (Freman, 2010; Carroll, 1996; Harrison, Freeman, 1999; Waddock, Bodwell, 2002; Philips, 2003; Post et al., 2002a, b) show that sustainable development of an organisation can be fostered by purposefully managing important relationships between the enterprise and its strategic partners. The author assumes that stakeholders are those identified external and internal forces that can impact the process of creation and promotion in a cultural enterprise.

Since the 1990s, cultural field researchers and economists (Klamer, 1999; Baumol, 2003, 1993; Aageson, 2008; Deakins, 1996) have already started a discussion on the development of cultural entrepreneurship, urging artists and their representatives to learn about selling art and orientation in the market. It is possible to determine an enterprise's stakeholders by analysing its objectives and consequently defining those groups without the support of which the enterprise would cease to exist.

The existing definitions of cultural management (Aageson, 2008; Hagoort, 2007; Klamer, 1999; Stam, 2006; Noordman, 2003) also do not provide precise suggestions for determining the most important indicators in the evaluation of cultural management. To substantiate the necessity for stakeholders' engagement and increase credibility, the author proposes to use AA1000 Stakeholder Engagement Standard (2015) that has been designed to underpin formal legal engagements between organisations and stakeholders.

To identify the stakeholders according to AA1000 Stakeholder Engagement Standard, the engagement objectives and scope have to be defined and analysis of the engagement process performed. When setting the engagement objective, economic, ecologic and social indicators have to be also identified together with the stakeholders, indicating to what extent the real enterprise's activities meet its objectives and values, the objectives and values of the stakeholders as well as the social norms and expectations in their broadest sense. The topical issues have to be found out with the help of the stakeholders to identify the scope of activities. The stakeholders have to be also engaged in the process of developing the information collection methods. Based on the gathered information, it is possible to evaluate whether the enterprise's activities correspond with the previously set values, goals and tasks (Zemīte, et al. 2011).

After evaluation and consultation with the stakeholders, the enterprise has to create or revise the future objectives and tasks to improve its performance. Cultural contents (the artistic values (Hoks, 2007) should be assessed first, followed by the evaluation of entrepreneurship processes and assets. The author believes that cultural entreprise management can be evaluated by defining and analysing the role of the stakeholders in managing cultural enterprises.

\section{Methodology}

The author characterises the research and analyses involvement of the stakeholders, substantiating it with empirical research data. The author's research data are analysed along with the understanding of cultural entrepreneurship environment on the importance of the stakeholders' engagement. On the basis of the analysed criteria for evaluation of cultural enterprises' activities, the management assessment is performed.

Positivism, interpretivism and pragmatism are the most often used paradigms in social sciences (Walliman, 2006: 19-20). The interpretivism paradigm provides that both deduction and induction methods are used for research (Gill, Johnson, 2010: 60), since the researcher does not view the research object from a distance, but is closely linked to the topic under discussion (Walliman, 2006: 20). The interpretivism paradigm is applied also to this research, as the explanation of subjective meanings of individuals is of the utmost importance within the context of research. During the course 
of empirical research, it is planned to disclose, analyse and interpret the subjective reasons of pursuit. The essence of research according to interpretivism is to reveal meaningful relationships and to discover the consequences of activities performed by individuals (Cohen, Manion, 1994: 10-11). For this particular empirical research, the author is oriented towards the research topics that can be perceived by experience-based intervention and by the ability to reach a wide perspective and evaluate the impact of culture (Johnson, Onwuegbuzie, Turner, 2007). It is important to be knowledgeable in the research topic to perform the qualitative research sampling (Kroplijs, Raščevska, 2010: 80), since qualitative research is aimed towards exploration of experience or knowledge acquired during practice; qualitative research methods are used for this empirical research.

The data structure of qualitative research appears during the course of the analysis (Punch, 2005: 57). In many cases it is not enough to use only one method of evaluation to answer the questions of research (Vondal, 2010: 2); therefore, to obtain a more precise point of view from the respondents and to get closer to the daily thinking patterns of the respondents (Branner, 2004: 313), the numerical value of the evaluation of stakeholders' importance was obtained. The task of qualitative research is to discover general dimensions, by learning about the categories and notions used by particular respondents (Kroplijs, Raščevska, 2010: 120). Although a numerical evaluation of stakeholders was obtained during the research and data analysis performed by Spearman's rho correlation calculations, the obtained results during the interpretation have not been generalised. Data analysis performed with the help of the tests substantiate trends and supplement the qualitative data (Branner, 2004, 314). The research results reflect the dominating point of view.

Evaluation of cultural entrepreneurship performed by 42 culture enterprises - art galleries, nongovernmental theatres and concert organisations - was done by the owners or managers of cultural enterprises. To facilitate the respondents to express their point of view clearly and understandably, the author included numerical evaluation of the stakeholders' impact according to the Likert scale from 1 to 5 points ( 5 - very important, 4 - important, 3 - somewhat important, 2 - not very important, 1 - not important at all). The quantitative data added to the qualitative investigation supplement research (Cropley, 2002: 39). The numerical evaluation provided by the managers of the art galleries was summarised by applying SPSS statistical analysis software, using non-parametric tests for the data processing. Non-parametric tests can be applied in cases of small sample size (Baggion, Klobas, 2011). The author defined that a stakeholder gaining the importance indicator lower than 3 points (somewhat important) is not considered effective for achieving the objectives of an organisation, and thus cannot be defined as necessary for ensuring the operations of the enterprise.

\section{Results}

The research is done with the cooperation of Latvia's cultural enterprises with the stakeholders and their role within the management of cultural enterprises. To assess the way by which the stakeholder's evaluation is linked to the longevity of an enterprise's operation, Spearman's rank correlation coefficient was calculated (since all data are in metric scale, while the empirical division does not correspond the normal ratio) (see Table 1).

Table 1. Spearman's rank correlation coefficient of stakeholder's engagement (Source: author's compilation)

\begin{tabular}{|l|c|c|c|c|c|c|}
\hline Stakeholders & $\begin{array}{l}\text { Art } \\
\text { scientists }\end{array}$ & Clients & Artists & $\begin{array}{l}\text { Cooperation } \\
\text { partners }\end{array}$ & Media & $\begin{array}{l}\text { Third party } \\
\text { funders }\end{array}$ \\
\hline Art scientists & 1,000 &,- 074 &, 096 &, 235 &, 252 &, 161 \\
\hline Clients &,- 074 & 1,000 &, 004 &, 108 &, 188 &, 043 \\
\hline Artists &, 096 &, 004 & 1,000 &,- 015 &,$- 404^{*}$ &,- 140 \\
\hline Cooperation partners &, 235 &, 108 &,- 015 & 1,000 &, $374^{*}$ &, 056 \\
\hline Media &, 252 &, 188 &,$- 404^{*}$ &, $374^{*}$ & 1,000 &, 254 \\
\hline Third party funders &, 161 &, 043 &,- 140 &, 056 &, 254 & 1,000 \\
\hline Length of operation &, 134 &, 146 &,- 209 &, 071 &, $607^{* *}$ &,- 204 \\
\hline
\end{tabular}

${ }^{*} \mathrm{p}=0.05$

$* * p=0.01$ 
The research results indicate that there is no statistically significant difference between the evaluation of stakeholders such as art scientists, clients, artists, media, cooperation partners and third party funders.

The results prove medium positive correlation between:

- Media and cooperation partners;

- Media and length of operation.

Media as an important stakeholder has been evaluated by a comparatively high average ratio of 4.35 points (see Table No. 2). However, when performing the analysis of involvement, the managers of cultural enterprises evaluate the cooperation with media as being basically negative or neutral. Consequently, the longer the operation of the enterprise, the more important is media as stakeholders in the perception of the enterprise's manager. This correlation proves that involvement of the stakeholder ensures long-term activities of the enterprise, since an understanding of the importance of stakeholders' involvement is formed only after some period of time. The cooperation partners as important stakeholders has been evaluated by the lowest average ratio of 3.60 points (see Table No. 2). However, the correlation indicates that the higher the evaluation for the importance of media, the more valuable the significance of the cooperation partners. The author assumes that this correlation is determined by the cultural enterprises' managers' comprehension of the way of ensuring activities; those who understand the importance of the cooperation partners in ensuring the enterprise's operations appreciate also the role of media.

The results prove medium negative correlation between:

- Media and artists $(r=-0,404, p=0,013)$.

This correlation proves the specificity of cultural entrepreneurship, as those managers of cultural enterprises who are too oriented towards achieving artistic results do not evaluate cooperation with other stakeholders as very important. 'Media are opposed to artistic values and consider them less important and, although oriented towards the society, are ignorant stakeholders. This has been proved also by the assessment of media involvement. On the contrary, those managers of cultural enterprises who understand the importance of stakeholders, have evaluated the significance of artists and consider them as components with the same importance, as are other stakeholders.

The average ratio of stakeholders indicates that all the above-mentioned stakeholders are important for ensuring the activities of cultural enterprises, as the medium ratio exceeds 3 points and remains between 3.60 to 4.79 points (see Table 2). Although creation of artistic value, self-expression and personality development has been perceived as the basic meaning of a cultural enterprise's existence, the research results indicate that managers of cultural enterprises perceive their clients as the main stakeholders. Orientation towards the client and understanding of the importance of artistic values dissemination indicate the necessity of the notion of cultural entrepreneurship, as the basic concept of entrepreneurship is implemented in reality.

Table 2. Importance of the stakeholders engagement (Source: author's compilation)

\begin{tabular}{|c|c|c|c|c|c|c|}
\hline & $\begin{array}{c}\text { Art } \\
\text { scientists }\end{array}$ & Clients & Artists & $\begin{array}{c}\text { Cooperation } \\
\text { partners }\end{array}$ & $\begin{array}{c}\text { Media } \\
\text { Third party } \\
\text { funders }\end{array}$ \\
\hline Medium & 3,66 & 4,79 & 4,70 & 3,60 & 4,35 & 3,83 \\
\hline Medium in fine arts & 3,70 & 4,68 & 4,81 & 3,27 & 4,29 & 3,77 \\
\hline Medium in performing arts & 3,60 & 4,91 & 4,53 & 4,10 & 4,43 & 3,93 \\
\hline
\end{tabular}

The author assumes that the criteria discovered during the analysis of the stakeholders' involvement can be generalised and attributed to the evaluation of activities performed by the art galleries. However, the above-mentioned criteria provide also perspectives that can be applied when analysing cultural enterprises, as they determine the importance of the stakeholders' involvement in cultural enterprise's management. Based on the results of the content analysis of the cultural enterprise 
managers' point of view and evaluation of the stakeholders, the author has summarised the main directions and perspectives for evaluation of the cultural sector enterprises - viability, growth and influence.

The author presumes that, to define the goal of the stakeholders' (artists, clients, media, arts scholars, third parties providing funds, cooperation partners) engagement, it is necessary to analyse the area of enterprise's activities, and in what way and by what kind of activities it is possible to engage the stakeholders.

The research results reveal that, basically, personal reasons and common artistic perception is the reason for engagement. The research results prove that viability can be ensured by engaging the most important stakeholders and appreciating the employees, as well as by evaluating the quality of cultural products that are crucial for development. The growth in international markets is also one of the perspectives for development. Information about Internet environment and public space on the activities performed ensures efficiency. It is possible to evaluate the management of cultural enterprises by ensuring the process of relationship management with those stakeholders who, in the case of engagement, would impact an enterprise's development, thus determining the role of the stakeholders' engagement in the management of the cultural enterprise. In creating artistic value and offering it for public assessment, the stakeholders' engagement relationship created by the cultural enterprise and its manager with those groups could impact the process of creating and disseminating artistic value.

The evaluation of cultural enterprise management can be applied in future research, after adapting it for use in the state and non-governmental sector with the purpose of identifying the stakeholders and evaluating their engagement. The author proposes the following hypothesis for future research: development of cultural enterprises could be fostered and state subsidies could be reduced by increasing the engagement of stakeholders in activities of the state sector cultural organisations.

\section{Conclusions}

Cultural entrepreneurship environment is formed and determined by the stakeholders, as the artists create the product contents; the audience (visitors, clients) approve the product's necessity; media provide its evaluation, attract attention and inform the audience, helping to reach it; the art scholars, critics and experts ensure professional evaluation within the branch context and motivation of work, while the third party funding sources can ensure independence for the cultural enterprise, and cooperation partners give possibilities for developing ideas and artistic programmes that would not be possible for the enterprise alone.

When comparing the research results with those determined by The AA1000 Stakeholder Engagement Standard, the main reasons for engaging the artists are as follows: the artistic value, ensuring the activities, personal reasons, possibilities for development and growth and sustainable cooperation.

Spearman's rho correlation confirms the specificity of cultural entrepreneurship, as those managers of cultural enterprises who are oriented towards achieving artistic results, do not evaluate the cooperation with other stakeholders too high and appreciate cooperation with stakeholders only in the long term.

By taking into account the stakeholders' needs, the scale of the enterprise's objectives is broadened. According to The AA1000 Stakeholder Engagement Standard, the management functions and the empirical research findings, three procedures are important for aligning the enterprise's interests with those of the stakeholders: defining the enterprise's objectives and results to be achieved, identifying the stakeholders and engaging the stakeholders in setting the directions of the enterprise's activities.

Criteria for assessing cultural enterprise's activities can be defined in three directions, namely, basis viability, growth and influence.

The criteria for evaluation of the viability are as follows: involvement of the existing clients and generation of interest among the potential customers, by developing an understanding and necessity to attend exhibitions; purchase art-works; recognising and evaluating artistic values; ability to find clients (the audience); ability to attract and keep clients (the audience); ability to generate interest among 
clients (the audience) about the product offered by the cultural enterprise; interest of clients and visitors about the art-works (attendance of exhibitions, purchases of art-works) and number of clients (in the data base, clients receiving additional services; ability to attract third party funding.

The two criteria for evaluation of growth are as follows: artistic success (product quality appreciation in the branch: the number of nominations and awards; invitations to participate in prestigious arts fairs, competitions, festivals) and personal growth (possibility to grow, learn and perfect one's knowledge; possibility for employees to elaborate some kind of activities; possibility for volunteers to undertake new duties and responsibility, to meet in person representatives of the stakeholders).

The criteria for evaluation of the influence are as follows: ability to ensure activities attracting the interest of other stakeholders (information in Internet environment and public space on the activities carried out by the cultural enterprise: the published news and their quality, media channels and their quality); bringing to the forefront issues important for society (activities noticed and appreciated by the clients, media and other cooperation partners); solving social issues with the help of art (opinion leaders developed by the cultural enterprises); ability to attract the third party funding: sponsors and patrons for publishing the artist catalogues) and ability to attract funding of foundations for performing various activities that promote art and culture in a broader society.

The average ratio of stakeholders indicates that all the above-mentioned stakeholders are important for ensuring the activities of cultural enterprises, as the medium ratio exceeds 3 points and remains between 3.60 to 4.79 points. Although creation of artistic value, self-expression and personality development has been perceived as the basic meaning of cultural enterprise's existence, the research results indicate that managers of cultural enterprises perceive their clients as the main stakeholders. Orientation towards the client and understanding the importance of artistic values dissemination indicate the necessity of the notion of cultural entrepreneurship, as the basic concept of entrepreneurship is implemented in reality.

\section{References}

Aageson, T.H. (2008). Cultural Entrepreneurs: Producing Cultural Value and Wealth. The Cultures and Globalization Series: The Cultural Economy. London: Sage Publications, pp. 92-107.

AA1000 Stakeholder Engagement Standard (2015). [Accessed 20.02.2016]. Available from http://www.accountability.org/standards/aa1000ses.html

Baggio, R., Klobas, J. (2011). Quantitative Methods in Tourism: A Handbook. Aspects of Tourism Series. Bristol, UK: Channel View, p. 255.

Baumol, W.J. (1993). Formal Entrepreneurship Theory of economics: Existence and Bounds. Journal of Business Venturing, 8, pp.197-210.

Baumol, W.J. (2003). On Austrian analysis of entrepreneurship and my own. Austrian Economics and Entrepreneurial studies. UK: Elsevier Science, pp.57-66.

Brannen, J. (2004). Working qualitatively and quantitatively. Qualitative Research Practice. Seale, C., Gobo, G., Gubrium, J.F., Silverman, D. (eds.). London: Sage Publication, pp. 312-326.

Carroll, A.B. (1996). Business and Society - Ethics and Stakeholder Management (3rd ed.). Cinncinati:South Western Publishing, p. 560.

Cohen, L., Manion, L. (1994). Research Methods in Education. London: Routledge, pp. 718.

Deakins, D. (1996). Entrepreneurship and small firms. London: McGraw-Hill, p. 248.

Freeman, R.E. (2010). Strategic Management: a Stakeholder Approach. New York: Cambridge University Press, p. 279.

Gill, J., Johnson, P. (2010).Research methods for managers. Los Angeles: Sage, p. 270.

Haagoort, G. (2000). Arts management entrepreneurial style. Eburon: Delft, pp. 214-215.

Harrison, J.S., Freeman, R.E. (1999). Stakeholders, social responsibility and performance: empirical evidence and theoretical perspectives. Academy of Management Journal, 4 (5), pp. 479-485. 
Hoks, Dž. (2007). Ilgstpējīgas attīstības 4. pīlārs. Kultūras nozīme valsts attīstības plānošanā. Cēsis: Culturelab, 51.-52. lpp.

Jagersma, P.K. (2009). The strategic value of sustainable stakeholder management. Business Strategy Series, 10 (6), pp. 339-344.

Johnson, R.B., Onwuegbuzie, A.J., Turner, L.A. (2007). Toward a Definition of Mixed Methods Research, Journal of Mixed Methods Research. 1 (2), pp. 112-133.

Klamer, A., Veldhuis, O. (1999). Cultureel ondernemerschap: wat is dat eigenlijk? NRC Handelsblad, 23.

Kroplijs, A., Raščevska, M. (2010). Kvalitatīvās pētniecības metodes sociālajās zinātnēs. Rīga: SIA "Izdevniecība RaKa", 190 lpp.

Lindlof, T.R., Taylor, B.C. (2002).Qualitative communication research methods (2nd ed.) Thousand Oaks, CA: Sage, p. 357.

Morgan, D.L., Krueger, R.A. (1997).The Focus Group Kit. Thousand Oaks, CA: Sage, p. 692.

Noordman, D. (2003). Kunstmanagement. Den Haag: Elsevier, pp. 13-17.

Stam, E. (2006). Coaching for Cultural Entrepreneurship. Rotterdam: Rotterdam Erasmus University, 126 lpp.

Philips, R. (2003). Stakeholder Theory and Organizational Ethics. CA: Berrett-Koehler, San Francisco, 200 lpp.

Post, J.E., Preston, L.E., Sachs, S. (2002a). Redefining the Corporation, Stakeholder Management and Organizational Wealth. Stanford: Stanford University Press, p. 320.

Post, J.E., Preston, L.E. Sachs, S. (2002b). Managing the extended enterprise, the new stakeholder view. California Management Review, 45 (1), pp. 1.-23.

Punch, K.F. (2005). Introduction to social research: quantitative and qualitative approaches. London: Sage Publications, p. 320.

Reṇge, V., Austers, I. (2004). Kvalitatīiās metodes sociālo priekšstatu pētījumos. Latvijas Universitātes raksti, 682: $29-40$.

Vondal, P. (2010). Conducting Mixed-Option Evaluations Performance Monitoring \& Evaluation TIPS.

Washington DC, USAID Center for Development Information and Development Evaluation. [Accessed 20.02.2016]. Available from http://transition.usaid.gov/policy/evalweb/documents/TIPS-

ConductingMixedMethodEvaluations.pdf

Walliman, N. (2006). Social research methods. London: Thousand Oaks, p. 224.

Waddock, S., Bodwell, C. (2002). From TQM to TRM: emerging responsibility management approaches.Journal of Corporate Citizenship, 7: 113-126.

Zemīte, I., Janovs, V., Luka, I. (2011). Quality benchmarking methodology: Case study of finance and culture industries in Latvia. Acta univ.agric.et silvic.,2: 385-390 